\title{
New Paradigm in Millennial Business: A Case Study of Pilona Coffee, Tangerang City
}

\author{
Tri Anggreni ${ }^{1)}$ \\ tri.anggreni@ubd.ac.id \\ Canggih Gumanky Farunik2) \\ canggih.farunik@ubd.ac.id \\ Hendra ${ }^{3)}$ \\ hendra.hendra@ubd.ac.id
}

1) 2) 3)Bussiness Faculty, University of Buddhi Dharma

\begin{abstract}
Millennial has its own character of thinking, because when compared to the previous generation who carried out the process of adaptation to the development of information technology, millennial grew and lived with the technology. They thrive with memes, digital markets, electronic money, and social media networks. Virality makes something quickly famous and quickly forgotten, collective memory is limited to how long digital traces can last on the internet. On the basis of that problem, this study was prepared with the question "What is the character of millennial leadership based on the organizational culture of the natural ecosystems they have built?" The purpose of this study is to understand the cultural character of millennial organizations based on their natural ecosystem so that they influence the lead character.

This study uses a qualitative method with close observation within a certain period of time for several millennial adolescents involved in the organization as the main sample, categorized based on their level of exposure to the internet. The expected outcome of this research is a deep understanding of how millennial organizational culture influences the character of its leadership.
\end{abstract}

Keywords: Bussiness Paradigm, Milenial, Enterpreneurship 


\section{PRELIMINARY}

Millennial is a term that is attached to the generation of humans who were born in the most recent time span in Indonesia. There are several different views regarding the meaning of millennial itself. According to the Alvara Research Center, Millennials are the generation born in 1981-2000, taking into account the increasing middle class in urban areas of this age range, such as Jakarta and other big cities. This view is also reinforced by CSIS data which categorizes Indonesian citizens aged 17-19 years as millennials. However, the author is more of the view that millennials are the generation of Indonesian people who are influenced by the rapid growth of the information technology industry which reached its peak in 2014, after 4G technology was launched. Many people are of the view that the advancement of $4 \mathrm{G}$ technology, encourages an era of information openness that has never been imagined by previous generations in Indonesia. Some circles even call it the disruptive era, or the era full of "disturbances".

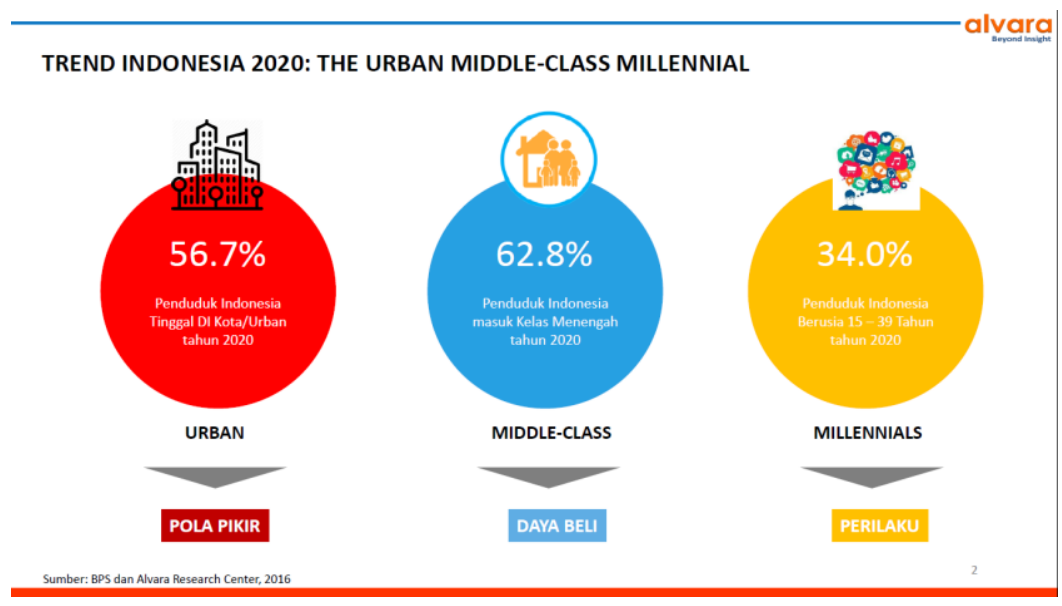

Picture 1. Indonesian Trend 2020

The author does not use the word disruptive, because the term was created by a generation who understands that human sociality is well-established and steady, and the vulgarity of information in this era is considered to "disturb" the steady social order. The term that is more appropriate to describe the era of information disclosure from a millennial perspective is the era of mobility, electronics, digital, and in networks. There is a reason why the term is used, namely because the socio-economic products born from this era are a transition from physical encounters to encounters through electronic or digital-based information technology intermediaries online (in networks) and realtime (interactions occur without time lag). Products and services in this era are then synonymous with electronic and digital terms, such as e-money, e-mail, digital printing, mobile banking, online motorcycle taxis and so on. For millennials, this era is their ecosystem with all the conveniences they can access via the internet and their devices, but for previous generations, this era was a disruption to social stability. 


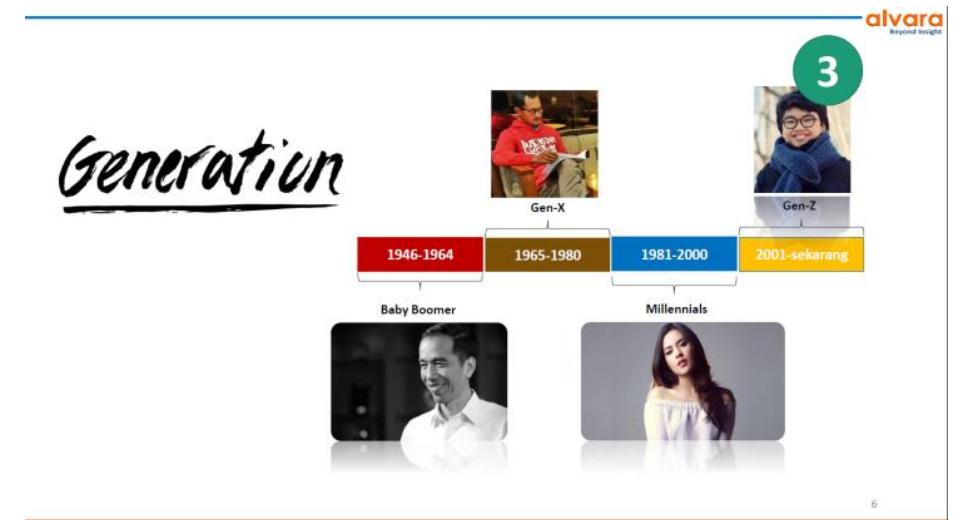

Picture 2. Generation Classification based on Year of Birth

The socio-political issue in the tug of war between the two paradigms developed by two different generations in Indonesia, encourages the dynamics between the traditional generation and the digital generation. One of these dynamics is the development of digital start-ups whose mechanisms are not understood by the traditional generation who are currently mostly regulators in the Indonesian government, thus influencing policy making regarding this business model. Millennials are aware that technological developments cannot be controlled by humans, therefore they mingle and intertwine in the direction of these technological developments. Millennial's drive to "internet" reality also makes exposure to sociality and easy events to become viral, and this activity is increasing in the era of $4 \mathrm{G}$ communication networks. The virality of a social event that occurs among millennials is breaking down the moral boundaries that have been controlled by the relevant authorities. The vulgar access to information with various alternative points of view, millennial responds in trivial ways too, such as, so that the author personally views that millennial is a generation that is completely different from the previous generation, when exposure to the internet and information technology was not as easy as it is today.

Based on this background, this study will focus on the development of organizational culture that occurs in the new era of information technology. The urgency of this research is to encourage a re-analysis of the development of information technology absorbed by millennials, to criticize what happens due to moral judgments on the use of information technology which is often assumed to be negative, then to reinterpret business development patterns in the original millennial 'habitus'. This research has a problem formulation that is specific to the problem of the millennial community business paradigm as a review of cultural studies in organizations, namely as follows: "How does the character of the millennial community business paradigm have an impact on cultural development in organizations, especially when compared to the previous paradigm of society?". This study aims to explore the business paradigm of the millennial community, then understand its impact on cultural development in organizations. A significant paradigm shift will encourage drastic cultural changes and push the old paradigm to be a little irrelevant. cultural change will also drive changes in policies, moral systems, and shifting needs. 


\section{PROBLEMS}

This research has a problem formulation that is specific to the problem of the millennial community business paradigm as a review of cultural studies in organizations, namely as follows:

"How does the character of the millennial community business paradigm have an impact on the development of business culture itself, especially when compared to the previous paradigm of society?"

\section{RESEARCH PURPOSE}

This study aims to explore the business paradigm of the millennial community, then understand its impact on cultural development in organizations. A significant paradigm shift will encourage drastic cultural changes and push the old paradigm to be a little irrelevant. cultural change will also drive changes in policies, moral systems, and shifting needs.

\section{METHODS}

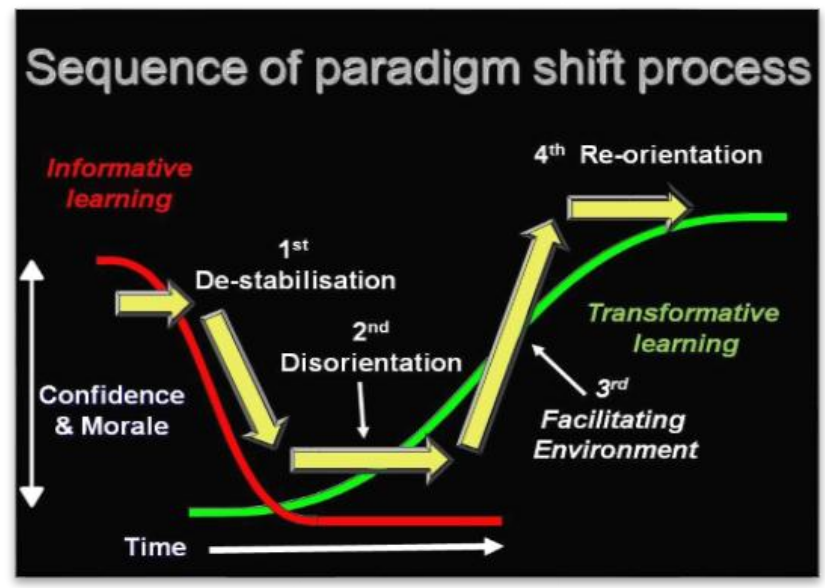

Picture 3. Paradigm Shift ${ }^{1}$

Thomas Kuhn's concept of paradigm shift is more often used to describe changes in the scientific tradition, from the old normal science to the new normal science, where this change does not occur in a short time, but from a fairly complex process, and change is also not about the development of variables. only, but also replace the entire system of thought. On the basis of understanding, a paradigm shift or paradigm shift can be used as a theoretical basis in seeing the phenomenon of changing patterns and systems in business developed millennials with a completely different perspective, beyond the definition of the previous generation. The paradigm change process begins with:

- De-stabilization, when the initial crisis point is marked by the emergence of anomalies. Community groups with a certain paradigm, as much as possible maintain the continuity of that paradigm as long as possible (status quo). The method used is usually to apply the formulation of a solution (theory) to answer all the problems that arise. The problem is, the inheritance of the theory is often imperfect, and it is actually carried away with the early generations of society. This is exacerbated by a new generation culture that is increasingly undisciplined,

${ }^{1}$ (https://i.pinimg.com/originals/2c/da/84/2cda84494421078d835dd86e8c19a37e.jpg, n.d.) 
rebellious, and trying to create new boundaries. Anomalies may arise from odd phenomena that the old theory could not solve, or arise from the younger generation themselves who tend to become more efficient and begin to discover ways that the old generation cannot solve.

- Disorientation, the emergence of anomalies encourages disorientation for all parties. This right occurs because a clash of solutions between the younger generation and the older generation might occur. The old generation wants an expansion of the old theory, arguing that so far the old theory can survive and become a solution to previous problems, while the new generation thinks that the old theory is not good enough to answer the new phenomenon.

- Facilitating Environment, in this situation, it can be said that the preparation for the new normal is by compiling a new theoretical set of two genera- tions, whether it is totally changing (assimilative) or compromising with the old theory (acculturative). A quite radical change in the assimilative paradigm is a change from geocentricflat-earth theory to heliocentric-spherical-earth theory, a change in acculturative paradigm occurred in the development of Newton's laws of universal motion to Einstein's theory of relative motion.

- Re-orientation, this is where a new normal point or towards a new normal paradigm point that is different from the previous one. At this point, the new paradigm will develop into the status quo and persist for some time until then new anomalies reappear. How long or not a paradigm can develop, really depends on how long a paradigm can last and is able to answer problems that arise in the future.

Kunt's Paradigm Shift Theory is used to understand a paradigm shift or shift from one business to another. The businesses that are used as a comparison are the "premillennial" and "millennial" coffee cafe businesses with the following research steps:

1. Determine the point of "de-stabilization" of the "pre-millennial" coffee cafe business based on its causes (internal and external factors), then determine when and where a new generation will emerge and encourage anomalies.

2. Determine the point of disorientation when anomalies appear and form new phenomena and trends among coffee connoisseurs and the coffee business itself.

3. Describe the point of "facilitating environment" where the conditioning of the business environment due to new developing trends can encourage change to the new normal.

4. Conclude the re-orientation point

\section{RESEARCH RESULT}

The author does not challenge the changing times with a pessimistic perspective such as disruption, but tries to see it from a millennial perspective and understands their way of thinking as 'users' of information technology devices so as to form a habituation that millennials are not aware of. If millennials are users, then the previous generation (premillennial) is a society that plays a role in building a 'millennial habitat' with the information technology they produce, so that the position of the pre-millennial generation can be called an 'author'. The dimension of reality that the writer wants to build is that pre-millennials as 'authors' are conscious subjects who encourage the 
development of information technology with simple motivation, namely business interests, while millennials as 'users' are passive subjects who absorb this technology as part of their social culture. . For pre-millennials, the millennial lifestyle is relatively new and not easy to understand from a conservative point of view. The phases can be seen in the illustration below:

\begin{tabular}{|c|c|c|c|c|c|}
\hline 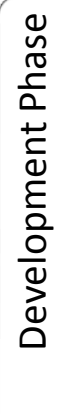 & $\begin{array}{l}\text { Perkiraan waktu sejak } \\
\text { diciptakannya 'mobile } \\
\text { phone' dengan } \\
\text { teknologi GPRS tahun } \\
1995 \text { hingga } \\
\text { ditemukan teknologi } \\
3 G \text { di tahun } 2003 . \\
\text { gawai adalah } \\
\text { komoditas ekonomi } \\
\text { baru }\end{array}$ & 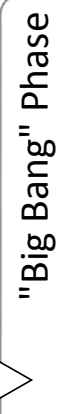 & $\begin{array}{l}\text { Meski } 3 G \text { meletakkan } \\
\text { gaya hidup baru } \\
\text { dalam berkomunikasi, } \\
\text { namun ledakan } \\
\text { sesungguhnya terjadi } \\
\text { di era } 4 G \text { sekitar } \\
\text { tahun } 2015 \text {. } \\
\text { pertukaran informasi } \\
\text { menuju 'real time' } \\
\text { tanpa kendala 'buffer' } \\
\text { seperti dalam jaringan } \\
\text { 3G. }\end{array}$ & 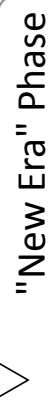 & $\begin{array}{l}\text { Fase ketika } \\
\text { infrastruktur dan } \\
\text { aktivitas jaringan } 4 G \\
\text { berjalan mapan, dan } \\
\text { membuka ruang- } \\
\text { ruang aktivitas } \\
\text { ekonomi dan bisnis } \\
\text { yang tidak pernah ada } \\
\text { sebelumnya. }\end{array}$ \\
\hline
\end{tabular}

Picture 4. Phase of Technology Development and its Impact on Business

The old paradigm in this case is an administrative system with full control or control over the authority. Meanwhile, the new paradigm being developed by millennials is still in the stage of looking for forms, but leads to a deconstructive view of authority. Referring to the "paradigm shift" theory pioneered by Thomas Kuhn, a paradigm shift occurs by starting with an anomaly. Anomalies exist because there are several causes, one of which most often happens is that the old paradigm is unable to solve new problems that continue to arise, precisely when the old paradigm tries to answer old problems through their point of view.

The trend of cafes and coffee shops has penetrated Indonesia since time immemorial. Since the days of powdered coffee, the roasting and milling processes are still very simple, and coffee shops are just the process of brewing or brewing coffee grounds into coffee drinks. There are many coffee brewing processes in a coffee shop or cafe, but they form different trends from one another, so it can be concluded that the social class gap makes the coffee drinking trend different. This has been seen since the arrival of Starbuck Coffee in 2002 at Plaza Indonesia, changing the trend of drinking coffee from brewing to roasting as well. This is supported by more modern and practical tools, so that the roasting process can be done in a shorter time. The coffee trend, which was initially enjoyed only from the type of coffee, has expanded to the roasting process as well. Not only that, the content and ingredients of its presentation are also experiencing development. Modern coffee connoisseurs try to pursue the original, bitter taste of coffee by minimizing other mixtures such as sugar or milk cream. The modern brewing process also makes it possible to make coffee without pulp, in contrast to traditional coffee shops which maintain the serving of coffee with grounds. Even so, traditional coffee shops and modern coffee shops do not interact or change trends, because they are consumed by people from completely different social classes. This is because the price difference is quite significant between the two. Espresso coffee in modern cafes has reached the price of tens of thousands of rupiah, while in coffee shops it is not more than the range of five thousand rupiah to ten thousand rupiah. So the existence of a coffee cafe is more to add variety to the presentation of coffee with a consumer market that is completely different from traditional coffee shops 
Over time, in 2007 onwards, a new trend emerged from coffee cafes turning into places to socialize. This has been accompanied by the growth of internet network infrastructure, such as wi-fi hotspots and increasingly affordable devices. The existence of these two facilities is an alternative for the community, especially the young and middle class, to access the internet, when cellular telecommunication service providers charge quite expensive tariffs for accessing the internet. Coffee cafes are not only a place to enjoy coffee, but also a place for socializing and recreation. This phenomenon encourages coffee cafe entrepreneurs to be more creative in packaging their menus, because they realize that those who come to their cafe are not only coffee connoisseurs, but also other groups who don't really like coffee. Non-coffee menu variations such as chocolate, tea, juice, ice cream, are becoming quite popular. This situation is not considered ironic by coffee cafe entrepreneurs, because there has been a shift in the paradigm of coffee cafes, which was originally only to serve the coffee-loving community to a wider audience. This trend lasted for a long time until the emergence of $4 \mathrm{G}$ technology and a digital market place as well as a delivery service provider, such as Gojek and Grab.

Millennials build new business ecosystems through digital infrastructure, which makes it easier to establish a new business with guaranteed affordability to consumers, while the consumer ecosystem itself is more flexible and dares to try new things. A new trend in coffee places that is not only a place to socialize, but also forms a new lifestyle, namely take-home delivery with an ecosystem of sociality in cyberspace, especially social media. Millennial people no longer enjoy coffee just because of the process from roasting to brewing which is typical of a cafe, but also adds new factors or elements, namely social media exposure or coffee business affordability to consumers by using exposure indicators such as hype, viral, trending.

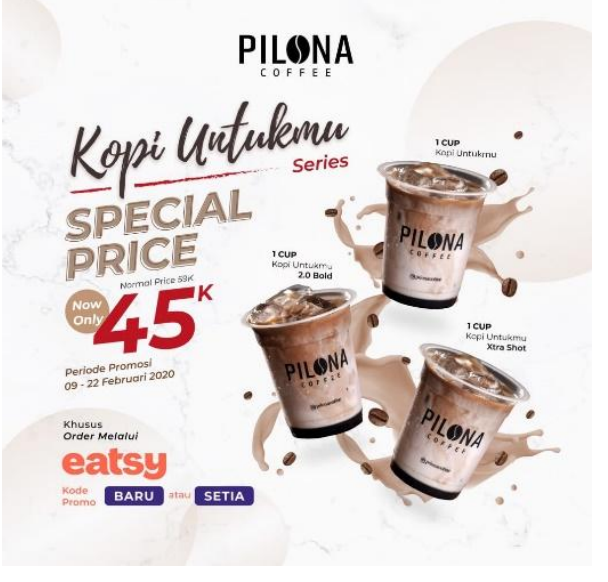

Picture 5. Pilona coffee promotion

One example of this millennial coffee business is Pilona coffee in Tangerang City. Pilona Coffee is located on Jl. Kisamaun No 161 Pasar Lama, Tangerang City. It was started by a businessman named Urip Nursalim (27 years old), who decided to start an innovation and collaborate with various existing online delivery and sales services and provide a 
wide variety of take away facilities, such as Gojek, Grab, Tokopedia and others. The take away facility also encourages the use of e-money facilities such as ovo, ovo point, gopay, izzy and others. Filona is one of many similar online coffee companies, some of which have even penetrated the national market and spread throughout Indonesia. The tradition of drinking coffee online has also changed the paradigm of drinking coffee itself. Entrepreneurs like Urip, no longer think of opening old-style coffee shops that cost a lot of money just to make customers feel at home for long in their cafes. Even lingering in a cafe is no longer the consumer paradigm today. The problem then is whether this change in the culture of the coffee consumer market has changed due to changes in the character of the coffee cafe, or vice versa. To answer this question, as a dynamic point of question in problem formulation, it will be answered through the theory of paradigm change as follows.

The point of de-stabilization lies in the days of start-up companies in the form of market places, delivery services, and the like. The rise of this start-up company, begins with a new trend in selling through social media. Social media was originally only a network of friends in the closest circle, personal data, testimonials, and pieces of documentation that were displayed to various media, such as photos, videos, documents, sounds. The spread of social media activities is due to the entry of public figures from various fields into social media. The size of social media is no longer mere emotional closeness, but also forms virtual closeness with strangers, public figures who are already well-known but not in their closest circle, to people who are initially unknown but whose life and works are considered interesting or phenomenal. . This phenomenal measure is very relative and subjective, but virality through certain statistical tools, such as likes, follow, subscribe, comments, mentions, and the like, proves to be phenomenal does not need clear or plausible reasons. In some cases on Twitter, something can become a trending topic even though many people do not know at all about the trending topic. This is due to the human ability to manipulate systems and mechanisms in social media, whether in simple ways, such as creating several fictitious or complex accounts such as manipulating algorithms, hacking accounts that have a large number of followers, or voiced by an organization that has a number of members. who are many and active simultaneously on social media with a specific purpose.

New trends in social media are virality, influence, to engagement. This social behavior is very attractive to various interests, and the most common are politics and business. Online business, before the emergence of market place type startups, started on social media. Online business involves product placement in works created by account holders with a large number of followers. Lately there has even been a special account for selling that is separate from the original account of the business owner. Social media has been transformed into an effective marketing tool, because of its reach across regions, even countries, at a low cost. Apart from the phenomenon of buying and selling followers, the author sees the phenomenon of social media itself as having expanded its function from just sharing personal life, becoming a "market" with all its virtual crowds. The emergence of market places such as tokopedia, shoppe, blibli, olx, to Bukalapak is the culmination of the dynamics of social media which has many shortcomings as a place to sell: products are determined by virality, not by need for these products. This results in the popularity of products that are not needed by someone, and not knowing the products that are needed. Market place startups try to 
separate social media from places to sell, and have proven quite successful so that now social media is only a marketing medium that provides a link to the market place. The coffee business, with an established digital ecosystem that extends from social media, market places, to freight forwarding services, provides many variations and business choices.

\section{CONCLUSION}

This research finds that millennial businesses are, to a lesser extent, influenced by the facilities provided by digital technology, be it the internet, mobile banking, online delivery services, virtual money, and so on. The ease with which account users can access to order coffee encourages a shift in the paradigm of "coffee shops" as a place to gather and socialize into a new social-digital trend. Communication connectivity is formed from virtual interactions via social media, while "coffee shops" are only places to buy coffee. The impact of this paradigm shift is that social connectivity, which was initially passed face-to-face with coffee shops as a medium of sociality, has transformed into a symbol of products and connectivity spaces have shifted from face-to-face to digital social media, by sharing products, impressions, testimonials so as to encourage people. who are in the sharing circle, buy the same product through an online ojek service.

\section{SUGGESTION}

The suggestions that the author wants to convey related to the results of this study are as follows: 1. For further research: in order to further deepen the influence of this paradigm shift on business opportunities which one day will become a new trend in the digital era. 2. For stakeholders and business people: to re-examine the transition of changing business paradigms as part of a socio-economic cultural transition from conventional to digital

\section{REFERENCES}

Ali, 2016, "Memahami Milenial Indonesia", Alvara Research Center

Survei Nasional CSIS “Orientasi Sosial, Ekonomi dan Politik Generasi Milenial”, Periode 23-30 Agustus 2017

Kuhn, Thomas, 1970, The Structure of Scientific Revolutions, University of Chicago: Chicago

Hardani dkk, 2020, Metode Penelitian Kualitatif dan Kuantitatif, Pustaka Ilmu Group: Yogyakarta 